\title{
PENGARUH BIMBINGAN UJI KOMPETENSI ONLINE TERHADAP HASIL TRY OUT LOKAL UJI KOMPETENSI MAHASISWA AKPER RS. DUSTIRA
}

\author{
THE INFLUENCE OF ONLINE-BASED COMPETENCY TEST GUIDANCE ON AKPER \\ RS. DUSTIRA STUDENTS' LOCAL TRY OUT OF COMPETENCY TEST RESULT
}

\section{Novi Malisa}

Akademi Keperawatan Rumah Sakit Dustira

Email: novimalisa53@gmail.com

\begin{abstract}
ABSTRAK
Latar Belakang: Uji kompetensi bertujuan untuk mencapai standar kompetensi lulusan yang memenuhi standar kerja sebagai tenaga kesehatan. Kelulusan uji kompetensi menjadi hal yang sangat penting untuk memperoleh pengakuan terhadap kompetensi yang dimiliki tenaga kesehatan. Berbagai metode telah diterapkan oleh Institusi untuk mempersiapkan mahasiswanya menghadapi uji kompetensi. Penelitian ini bertujuan untuk mengetahui pengaruh bimbingan uji kompetensi online terhadap hasil try out lokal uji kompetensi. Metode: Desain penelitian menggunakan one group pre-post test design. Populasi pada penelitian ini ialah mahasiswa tingkat III Akper RS. Dustira. Sampel penelitian sebanyak 125 responden diambil dengan teknik Purposive Sampling. Data diperoleh melalui try out online lokal uji kompetensi dengan jumlah soal 180 pertanyaan vignette yang telah disusun oleh tim yang tersertifikasi item development dan item review. Analisis data menggunakan uji paired t test dengan $\alpha=0,05$. Hasil: Hasil penelitian menunjukkan rerata nilai pre test sebelum diberikan intervensi adalah 46,9110 dengan $38,4 \%$ responden belum dapat memenuhi batas lulus. Rerata nilai post test setelah diberikan intervensi adalah 80,2845 dengan $100 \%$ responden dapat memenuhi batas lulus. Bimbingan online terbukti secara signifikan meningkatkan nilai mahasiswa saat try out lokal uji kompetensi $(\mathrm{p}=0,000)$. Diskusi: Bimbingan online dapat dijadikan metode alternatif untuk mempersiapkan mahasiswa menghadapi uji kompetensi.
\end{abstract}

Katakunci : Bimbingan online, Try out, Uji kompetensi

\begin{abstract}
Background: Competency test aims to achieve graduate competency standards that meet the work standards as a health worker. Therefore, the passing of competency test becomes very important for health worker to be able to obtain recognition of their competency. Various methods have been applied by educational institution to prepare the students for their competency test. The purpose of this research is to know the influence of online-based competency test counselling on Akper RS. Dustira students' local try out of competency test result. Method: The research design is one group pre-post test design. The population of this research is the third year students in Akper RS Dustira. The 125 respondents was taken by Purposive Sampling technique. The data was obtained through the local try out of competency test with 180 vignette questions that have been made by a team that has item development and item review certificate by online system. Data analysis used paired t test with $\alpha=0,05$. Results: The result showed that the average score of the pre-test before being given an intervention was 46,9110 with 38,4\% respondents unable to meet the passing grade. The average score of post test after being given a intervention is 80,2845 with $100 \%$ of the respondents meet the passing grade. Online guidance was proven can significantly improve students' score on local try out of competency test $(p=0,000)$. Discussion: Online guidance can be an alternative method to help the students to prepare for the competency test.
\end{abstract}

Keywords: Competency test, Online guidance, Try out
JURNAL

SKOLASTIK

KEPERAWATAN

VOL. 6 , NO. 1

Januari - Juni 2020

ISSN: $2443-0935$

E-ISSN 2443 - 16990 


\section{PENDAHULUAN}

Keperawatan adalah kegiatan pemberian asuhan kepada individu, keluarga, kelompok, atau masyarakat, baik dalam keadaan sakit maupun sehat (UndangUndang no.38 tahun 2014). Keperawatan merupakan suatu seni dan ilmu pengetahuan. Menurut American Nurses Association (ANA), 2003 dalam Potter dan Perry (2010) mendefinisikan keperawatan sebagai perlindungan, promosi, dan optimalisasi kesehatan dan kemampuan, pencegahan penyakit dan cedera, meringankan penderitaan melalui diagnosis dan penanganan respons manusia, dan advokasi dalam pelayanan individu, keluarga, masyarakat, dan populasi. Definisi tersebut menegaskan bahwa keperawatan memegang peran penting dalam menyediakan pelayanan kesehatan bagi masyarakat.

Keberhasilan pelayanan keperawatan dalam meningkatkan derajat kesehatan masyarakat tidak luput dari peran perawat profesional yang mempunyai andil besar dalam pencapaian mutu pelayanan keperawatan. Seorang perawat profesional harus memiliki pengakuan terhadap kompetensi yang dimilikinya sehingga dalam memberikan asuhan keperawatan, perawat tersebut sudah terbukti kompeten. $\mathrm{Di}$ Indonesia pengakuan terhadap kompetensi yang dimiliki oleh perawat dibuktikan dalam sertifikat kompetensi yang didapatkan setelah perawat tersebut lulus uji kompetensi (Peraturan Menteri Pendidikan dan Kebudayaan / Permendikbud No.2 tahun 2020). Oleh karena itu lulus uji kompetensi merupakan kunci utama seseorang dapat dinyatakan kompeten sebagai seorang perawat.

Proses uji kompetensi meliputi proses pengukuran pengetahuan, keterampilan, dan perilaku perserta didik pada Perguruan Tinggi yang menyelenggarakan pendidikan tinggi bidang kesehatan (Permendikbud No.2 tahun 2020). Uji kompetensi merupakan suatu bentuk penjaminan mutu lulusan pendidikan tinggi kesehatan dan kompetensi tenaga kesehatan di Indonesia, mengingat globalisasi dalam bidang kesehatan merupakan suatu peluang untuk meningkatkan kualitas tenaga kesehatan sehingga dapat meningkatkan kualitas pelayanan kesehatan dan kualitas tenaga kesehatan agar mampu bersaing dengan tenaga kesehatan asing yang akan bekerja di Indonesia maupun di pasar global (Apriany \& Romadoni, 2015).

Melihat komprehensifnya domain dari proses uji kompetensi ini maka persiapan untuk mendapat kelulusan uji kompetensi ini tidak bisa secara instan. Berdasarkan hasil studi pendahuluan yang dilakukan di Akper RS. Dustira, beberapa metode telah dilaksanakan untuk mempersiapkan mahasiswa menghadapi uji kompetensi diantaranya item development dan item review untuk menghasilkan soal-soal yang berkualitas, mengenalkan sedini mungkin soal-soal vignette kepada mahasiswa melalui ujian tengah semester dan ujian akhir semester, dan bimbingan / pembahasan soal kepada mahasiswa.

Metode bimbingan intensif sudah terbukti dapat meningkatkan pemahaman terhadap soal-soal uji kompetensi sebagaimana telah disampaikan oleh Choeron \& Metrikayanto (2020) dalam penelitiannya bahwa bimbingan intensif terbukti efektif meningkatkan kesiapan mahasiswa dalam menghadapi ukom ners. Namun pada tahun ini pelaksanaan metode bimbingan intensif menjadi berbeda karena kondisi yang diluar kendali yaitu adanya wabah covid-19.

Kondisi pandemi covid-19 yang terjadi pada awal tahun 2020, memberikan dampak yang sangat besar terhadap seluruh tatanan kehidupan termasuk proses pembelajaran. Dengan adanya kebijakan pemerintah untuk stay at home, physical and social distancing, dan study from home merubah metode pembelajaran tatap muka menjadi tatap maya yang dalam hal ini dilaksanakan secara online. Metode online ini menjadi pilihan utama dalam pembelajaran ketika adanya penerapan social distancing (Syarifudin, 2020). Kondisi ini memiliki tantangan dan hambatan tersendiri dalam pelaksanaan persiapan mahasiswa menghadapi uji kompetensi terutama dalam hal bimbingan 
intensif yang dilakukan dengan tatap muka. Salah satu alternatif adaptasi terhadap kondisi ini adalah merubah metode

\section{BAHAN DAN METODE PENELITIAN}

Desain penelitian yang digunakan adalah quasi experimental dengan rancangan one group pretest and postest design. Pretest dilakukan untuk mengetahui nilai awal try out lokal uji kompetensi sebelum dilakukan intervensi bimbingan online. Selanjutnya Postest dilakukan untuk mengetahui nilai akhir try out lokal uji kompetensi setelah dilakukan intervensi bimbingan online.

Populasi dalam penelitian ini adalah mahasiswa tingkat III Akper RS. Dustira. Jumlah sampel yang digunakan sebanyak 125 orang responden. Tehnik pengambilan sampel menggunakan Non Probability Sampling berupa tehnik Purposive Sampling dengan kriteria inklusi :

1) Mampu mengakses program bimbingan online melalui aplikasi zoom cloud meeting

2) Sehat (tidak mengalami penurunan status kesehatan)

Kriteria eksklusi adalah respsonden yang tidak mengikuti kegiatan bimbingan online secara penuh.

Tehnik pengumpulan data pada penelitian ini diawali dengan pengisian soal ujian pre test vignette sebanyak 180 soal yang dikerjakan secara online dari rumah masing-masing responden. Soal dikerjakan selama 180 menit. Setelah responden mengerjakan soal, responden diberi intervensi berupa bimbingan intensif secara online. bimbingan tatap muka menjadi metode bimbingan intensif online.

Bimbingan dilakukan setiap hari (seninjumat) mulai pukul 08.00-15.00 WIB melalui aplikasi zoom cloud meeting dengan jumlah peserta satu sesi bimbingan tidak lebih dari 50 orang. Penjadwalan bimbingan online dikelompokkan sesuai dengan departemen tinjauan keilmuan yaitu Keperawatan Medikal Bedah, Keperawatan Anak, Keperawatan Jiwa, Keperawatan Maternitas, Keperawatan Keluarga, Keperawatan Gerontik, Manajemen Keperawatan, dan Keperawatan Gawat Darurat.

Bimbingan online dilakukan selama 2 minggu dengan metode problems solving yaitu pemecahan kasus yang sering muncul dalam soal uji kompetensi. Diakhir sesi bimbingan, responden mengikuti ujian post test soal vignette.

Data diolah dengan menggunakan menggunakan uji korelasi menggunakan paired t test untuk mengetahui perbedaan rerata nilai pre-post test responden. Taraf signifikansi yang digunakan adalah $p=0,05$ dengan tingkat kepercayaan $95 \%$.

\section{HASIL}

Tingkat kompetensi sebelum dan sesudah diberikan intervensi bimbingan online dapat terlihat pada table berikut :

Tabel 1. Analisis Univariate Tingkat Kompetensi Saat Sesebelum dan Sesudah Intervensi

\begin{tabular}{lrrrrrr}
\hline \multirow{2}{*}{ Pengukuran } & \multicolumn{3}{c}{ Pre Intervention } & \multicolumn{3}{c}{ Post Intervention } \\
\cline { 2 - 7 } & Rerata Nilai & Frekuensi & Persentase (\%) & Rerata Nilai & Frekuensi & Persentase (\%) \\
\hline Kompeten & 46,91 & 77 & 61,6 & 80,28 & 125 & 100 \\
$\begin{array}{l}\text { Tidak } \\
\text { Kompeten }\end{array}$ & & 48 & 38,4 & & 0 & 0 \\
\hline Total & & & & & 125 & \\
\end{tabular}


Berdasarkan tabel 1 diketahui bahwa tingkat kompetensi sebelum intervensi adalah $61,6 \%$ kompeten dan $38,4 \%$ tidak kompeten. Tingkat kompetensi mahasiswa meningkat setelah diberikan intervensi yaitu sebanyak $100 \%$ mahasiswa kompeten.

Perbedaan rerata skor nilai pretest dan posttest dapat dilihat pada tabel berikut:

Tabel 2 . Analisis Bivariate Perbedaan Nilai Pretest dan Posttest Intervensi

\begin{tabular}{lrrrr} 
Variabel & Mean & SD & $\boldsymbol{t}$ & $\boldsymbol{p}$ \\
\hline $\begin{array}{l}\text { Nilai } \\
\text { Pretest }\end{array}$ & 46,91 & 4,82707 & $-120,083$ &, 000 \\
Posttest & 80,28 & 7,63840 & &
\end{tabular}

Berdasarkan tabel 2 diketahui bahwa terdapat perbedaan yang signifikan dalam nilai rerata kompetensi responden sebelum dan sesudah dilakukan intervensi bimbingan online dengan nilai $p=0,000$.

\section{PEMBAHASAN}

Hasil penelitian menunjukkan sebelum diberikan bimbingan online, masih banyak mahasiswa yang belum kompeten $(38,4 \%)$. Hasil ini mengindikasikan bahwa mahasiswa belum memiliki persiapan yang cukup untuk mengerjakan soal-soal dalam bentuk vignette seperti yang diujiankan dalam uji kompetensi. Melihat beberapa metode sebelumnya yang sudah di terapkan di Akper Rumah Sakit Dustira, ketidaksiapan mahasiswa ini bukan karena kurang terpaparnya dengan bentuk soal kasus (vignette) tetapi karena mahasiswa belum diberikan pemahaman terkait telaah soal dengan pendekatan problem solving. $\mathrm{Hal}$ ini harus menjadi perhatian khusus bagi Institusi untuk dapat menyusun program yang aplikatif berdasarkan evidance based sehingga program yang dirancang menjadi tepat sasaran. Keberhasilan dalam persiapan uji kompetensi ini tidak lepas dari kegiatan penjaminan mutu proses pembelajaran. Sinergitas antara keseluruhan proses persiapan, pelaksanaan, dan evaluasi pembelajaran menjadi salah satu kunci keberhasilan dalam mencapai kelulusan uji kompetensi.

Berdasarkan analisis nilai pre-test, diketahui sebanyak $61,6 \%$ mahasiswa yang berhasil dinyatakan kompeten melalui nilai pre test adalah mahasiswa yang memiliki nilai Indek Prestasi Kumulatif (IPK) di atas rata-rata. Hal ini sejalan dengan penelitian yang dilakukan oleh Rahadian (2018) dan Krisdianto \& Kusumawati (2019) yang mengungkapkan bahwa salah satu faktor yang menentukan kelulusan dalam uji kompetensi adalah IPK. Semakin tinggi IPK maka peluang untuk lulus uji kompetensi menjadi semakin besar, namun hal ini bukan berarti menutup kesempatan bagi mahasiswa yang memiliki IPK rendah untuk mencapai kelulusan dalam uji kompetensi. Oleh karena itu berbagai metoda pendekatan harus terus menerus dirancang, diterapkan, dimonitor, dan dievaluasi untuk mendapatkan metoda yang efektif dan efisien sesuai dengan situasi dan kondisi yang ada pada mahasiswa.

Intervensi bimbingan online yang dilaksanakan dalam penelitian ini menggunakan pendekatan pemecahan kasus yang sering muncul sesuai blue print uji kompetensi. Pada awal proses bimbingan, responden terlebih dahulu diberikan penjelasan mengenai struktur soal meliputi vignette, lead in, dan option, selanjutnya mahasiswa diberikan penjelasan mengenai blue print uji kompetensi, tips dan trik dalam memahami dan menjawab soal, pemahaman mengenai kasus, refreshing materi tentang prosedur tindakan keperawatan, dan pemberian motivasi kepada mahasiswa. Pemberian motivasi ini menjadi penting selain dari pemberian pemahaman terkait kasus karena prinsip pembelejarana online memberikan keleluasaan bagi peserta 
didik untuk melintasi ruang dan waktu (Pannen, 2016). Dengan kata lain, apabila mahasiswa memiliki motivasi yang tinggi maka ia akan berusaha sebaik mungkin untuk terjun dan larut dalam proses pemebalajaran online. Lain halnya dengan mahasiswa yang tidak memiliki motivasi maka proses pembelajaran yang diikuti hanyalah sebatas memenuhi kewajiban dari program yang telah ditetapkan. Motivasi yang kurang juga dapat menyebabkan mahasiswa menjadi tidak fokus dalam belajar, hal ini akan menjadi penghambat mahasiswa dalam mendapatkan kelulusan uji kompetensi sebagaimana di sampaikan oleh Kholifah \& Kusumawati (2017) bahwa tidak fokus belajar merupakan salah satu hambatan lulusan ners dalam menghadapi uji kompetensi ners Indonesia.

Efektifitas intervensi bimbingan online ini terbukti dengan meningkatnya nilai ratarata mahasiswa saat post test dan $100 \%$ mahasiswa dapat melampaui batas kelulusan yang ditetapkan dengan kata lain mahasiswa dinyatakan kompeten pada try out ini. Hasil yang signifikan ini tidak luput dari tingginya antusias mahasiswa saat melaksanakan bimbingan online dan positifnya persepsi mahasiswa terhadap bimbingan online yang dilaksanakan. Hal ini terlihat dari tidak adanya mahasiswa yang ijin untuk tidak mengikuti bimbingan. Selain itu, mahasiswa sangat aktif selama bimbingan online terbukti dengan bayaknya mahasiswa yang bertanya selama proses bimbingan dan menjadikan forum diskusi begitu interaktif. Hal ini juga diungkapkan oleh Saifuddin (2018) dalam penelitiannya yang mengungkapkan bahwa persepsi mahasiswa e-learning

\section{DAFTAR PUSTAKA}

Apriany, A., \& Romadoni, S. (2015). Hubungan Antara Tingkat Pengetahuan, Persepsi Dan Sikap Mahasiswa Tentang Uji Kompetensi Dengan Tingkat Kelulusan Try Out Uji Kompetensi Pada Mahasiswa Program Profesi Ners Uji Pertama Program Studi IImu Keperawatan Stikes bermanfaat, dapat meningkatkan motivasi, memudahkan memahami materi, membantu kesiapan dalam perkuliahan.

Penelitian lain yang sejalan dengan pentingnya kesiapan belajar bagi mahasiswa diungkapkan oleh Suciati (2017) yang mengungkapkan bahwa kesiapan belajar yang tercermin melalui self-efficacy, self-regulation, dan connectedness secara simultan memengaruhi kepuasan mahasiswa terhadap program belajar yang diikuti. Kepuasan mahasiwa diharapkan dapat membuat mahasiswa bertahan sampai ke akhir dan mencapai keberhasilan.

\section{KESIMPULAN}

Uji kompetensi bertujuan untuk mencapai standar kompetensi lulus yang memenuhi standar kerja sebagai tenaga kesehatan sebagaimana dijelaskan dalam Permendikbud Nomor 2 tahun 2020. Oleh karena itu kelulusan uji kompetensi menjadi hal yang sangat penting bagi tenaga kesehatan untuk dapat memperoleh pengakuan terhadap kompetensi yang dimilikinya. Untuk mencapai kelulusan uji kompetensi bukanlah hal yang mudah karena banyak sekali faktor yang berpengaruh dan salah satunya melalui penjaminan mutu proses pembelajaran dan penerapan program inovatif yang dirancang untuk mempersiapkan mahasiswa menghadapi uji kompetensi. Salah satu program yang dapat diterapkan ialah dengan memberikan bimbingan secara online kepada mahasiswa sesuai dengan hasil penelitian ini.

Muhammadiyah Palembang Tahun 2015. Masker Medika, 3(2), 48-54.

Choeron, R. C., \& Metrikayanto, W. D. (2020). Meningkatkan Kesiapan Uji Kompetensi Ners Melalui Bimbingan Intensif: Improving The Readiness of NERS Competence Test Through Intensive Guidance. Jurnal Ilmiah Keperawatan 
(Scientific Journal of Nursing), 6(1), 143-147.

Kholifah, S., \& Kusumawati, W. (2017). Hambatan Lulusan Ners Dalam Menghadapi Uji Kompetensi Ners Indonesia. The Indonesian Journal of Health Science, 7(1).

Krisdianto, M. A., \& Kusumawati, W. (2019). Faktor-Faktor Yang Mempengaruhi Kelulusan Uji Kompetensi Ners Indonesia (UKNI). The Indonesian Journal of Health Science, 11(1), 1-8.

Paulina Pannen, 2016, Kebijakan Pendidikan Jarak Jauh dan Elearning di Indonesia, Kemenristek Dikti

Peraturan Menteri Pendidikan dan Kebudayaan No.2 tahun 2020 tentang Tata Cara Pelaksanaan Uji Kompetensi Mahasiswa Bidang Kesehatan

Potter, P.A \& Perry, A.G. (2010). Buku ajar fundamental keperawatan konsep, proses, dan praktik. Jakarta : EGC.

Rahadian, D. Z. (2018). Faktor-Faktor Yang Mempengaruhi Kelulusan Uji Kompetensi Mahasiswa Profesi Ners Stikes Jenderal Achmad Yani Yogyakarta. Jurnal Wacana Kesehatan, 2(2).

Saifuddin, M. F. (2018). E-learning dalam persepsi mahasiswa. Jurnal Varidika, 29(2), 102-109.

Suciati, S. (2017). Interaksi Kesiapan Belajar Dan Kepuasan Terhadap Layanan Pada Pembelajaran Online Program Pascasarjana. Cakrawala Pendidikan, (1), 70-80.

Syarifudin, A. S. (2020). Impelementasi Pembelajaran Daring Untuk Meningkatkan Mutu Pendidikan Sebagai Dampak Diterapkannya Social Distancing. Jurnal Pendidikan Bahasa dan Sastra Indonesia Metalingua, 5(1), 31-34.
Undang-Undang no.38 tahun 2014 tentang Keperawatan. 